\title{
Improvement of Foam Characteristics of Tea by Natural Additives
}

\author{
Shweta M. Deotale, Sayantani Dutta, Moses JA, C. Anandharamakrishnan*
}

\begin{abstract}
Tea is one of the widely consumed beverages in the world. It is well known that conspicuous and stable foam on beverages attracts consumers. Foaming is common in coffee, beer and other beverages but of course, it is more than welcome in tea as well. For black tea a merged foam layer can be visible on the surface layer but coffee like foam is not obtained for any of the tea varieties. In order to increase foaming in tea, in this study, skimmed milk powder, whey protein and Tween 80 were used as additives at variable concentrations. Tensiometric analysis showed reduction in surface tension values with increasing concentration of additives in tea, indicating presence of surface active components therein. Also, GC/MS-MS analysis indicated the presence of caffeine and hydrocarbons as polar and non-polar components, respectively. Foam characteristics of tea analyzed using a dynamic foam analyzer indicated that $6 \%$ whey protein produced acceptable foam behavior in black tea.
\end{abstract}

Keywords - Tea, additives, foam structure, foam stability

\section{INTRODUCTION}

Tea (Camellia sinensis) is one of the widely consumed beverages in the world. Its characteristic aroma and taste are well known for stimulating the consumers and it is popular for export market also. For beverages such as coffee and beer visible foam has always been the key attraction; whereas, in case of tea, foaming is limited and lesser known. In case of green tea and black tea, little amount of foam is observed, but only without milk. This is because milk based tea contains milk protein casein that has been opined to be denatured during heating. In the production of dairy foam, casein plays important role and many researchers have found that foaming characteristics of dairy based beverages are influenced by the protein matrix in milk, even at times including that of whey [1].

Reportedly saponins are natural surfactant that can be used to stabilize nanoemulsions [2]. Therefore, in case of black tea and green tea, foaming could be owing to tea saponins. In the current investigation tea solution has been studied for evaluation of interfacial properties and thorough identification of polar and non-polar compounds responsible for foaming and improvement of tea foam by addition of skimmed milk

Shweta M. Deotale, Sayantani Dutta, Moses JA, C. Anandharamakrishnan* Computational Modeling and Nano Scale Processing Unit,

Indian Institute of Food Processing Technology,

Ministry of Food Processing Industry, Government of India,

Thanjavur 613005, Tamil Nadu, India powder, whey protein and surfactant. To the best of our knowledge till now no study has presented improvement of foaming behaviors of tea.

\section{II.MATERIALS AND METHOD}

\section{A. Materials}

Black tea bags and skimmed milk powder (SMP) were procured from the local market of Thanjavur, India. Whey protein (WP) (80\%) and Tween 80 were procured from Muscle Blaze, India and Hi-Media, Mumbai, India, respectively.

\section{B. Preparation of Solution}

Black tea was prepared by dipping 1 tea bag $(\approx 2.5 \mathrm{~g})$ into $100 \mathrm{ml}$ of boiling water and was kept for 3 min, resulting in an infusion [3], [4]. Further, different solutions were prepared with addition of additives at variable concentrations (WP \& SMP at $2-8 \%$ and Tween 80 at $0.01-0.1 \%$ ).

\section{Tensiometry Assessment}

Surface tension of all tea solutions (black tea and tea with additives with concentration $0.01 \%-10 \%$ ) were measured using KRÜSS K11 Tensiometer (Wilhelmy plate method). Initially surface tension of water was measured as $70.1 \pm 0.1$ $\mathrm{mN} / \mathrm{m}$. Then tea powder from tea bag in variable concentration $(0.01 \%-10 \%)$ was added into $100 \mathrm{ml}$ of water. Further additives were also added in same way in tea solutions, and surface tension was subsequently measured [5], [6].

\section{Foaming Characteristics}

The tea solutions with variable concentration were analyzed by Dynamic Foam Analyzer (DFA) system (DFA-100, KRÜSS, Germany). Herein, the samples were injected through a $60 \mathrm{~mL}$ syringe into a graduated cylindrical glass cell $(40 \mathrm{~mm}$ inner diameter), which was attached to the camera, to obtain high resolution images of the foam (KRÜSS DFA100, 2012). Compressed air was passed through the sintered glass frit (diameter $=50 \mathrm{~mm}$, thickness $=4 \mathrm{~mm}$, and pore size $=16-40$ $\mu \mathrm{m})$, being injected from the bottom of the cylindrical glass cell. Flow rate of the gas was set at $0.3 \mathrm{~L} / \mathrm{min}$ and was stopped after $30 \mathrm{~s}$ of foaming. Batch size was $40 \mathrm{~mL}$ for all measurement [7].

This method formed foam in the solutions. The foam height was measured after the foam achieved its maximum height and gained stability. To measure the improvement in tea foam formed due to additives, all tea foams were compared with 
coffee (control). Measurement of 2 dimensional foam was done using foam structure module, containing a high resolution camera (performance: $2 \mathrm{fps}$ at $1280 \times 1024 \mathrm{px}$; SchneiderKreuzmach Lens, Germany) to capture the photograph(s) of the foam with respect to time. The resulting images were analyzed by foam analysis software to obtain bubble size distribution. The mean bubble area and bubble count were recorded at regular time intervals of $30 \mathrm{~s}$, for $600 \mathrm{~s}$ at $70 \mathrm{~mm}$ above the glass frit, in an area of $10.5 \mathrm{~mm} \times 7.5 \mathrm{~mm}$ according to the method reported by Oetjen et al. [7].

\section{E. GC-MS/MS Analysis}

Compounds extracted by $n$-hexane and ethanol were subjected to Gas Chromatography - Mass Spectrometry/ Mass Spectrometry (GC-MS/MS) (BrukerScion 436-GC) analysis using BR-5MS column ( $30 \mathrm{~m} \times 0.25 \mathrm{~mm}$ ID $\times 0.25 \mu \mathrm{m}$ film thickness) and TQ quadrupole MS detector. Injector temperature was set at $180^{\circ} \mathrm{C}$. Oven temperature was maintained at $45^{\circ} \mathrm{C}$ for $15 \mathrm{~min}$ and was increased to $75^{\circ} \mathrm{C}$, at the rate of $3^{\circ} \mathrm{C} / \mathrm{min}$.

\section{F. Sensory Analysis}

The effects of addition of additives in tea were assessed with the help of sensory analysis by a semi-trained panel comprised of faculty members and research scholars of 22-40 age group. Panelists evaluated the tea and coffee samples based on the attributes of overall acceptance, colour, aroma, taste, flavour and after taste using 9-point hedonic scale (1-dislike extremely to 9-like extremely) [8], [9].

\section{G. Statistical Analysis}

All experiments were conducted in triplicates. One-way ANOVA was performed on the mean values of attributes tested for coffee and tea foams with additives, using Duncan's multiple range tests. The data were tested at significant level $p<0.05$ using IBM SPSS Statistics software version 20.0 (IBM, USA).

\section{RESUlTS AND DisCUSSION}

\section{A. Tensiometry}

The effect of surface tension plotted against concentration of black tea and its additives has been illustrated in Fig 1. Surface tension reduced from $70-71 \mathrm{mN} / \mathrm{m}$ to $41-43 \mathrm{mN} / \mathrm{m}$, with increase in concentration from $0.01 \%$ to $10 \%$, thereby explaining the presence of surface active agents. In the present work, additives in black tea showed insignificant effect on surface tension values (Fig 1).

Skim milk powder and whey contain protein which interacts with the air-water interface. Additives in the solution generally get displaced at interfacial film layer, or sometimes form protein-protein interaction or void spaces, due to improper packing of molecules at air-water interface [10]. Owing to these effects, surface tension value of tea solution was found to be increasing at initial stage before it became constant.

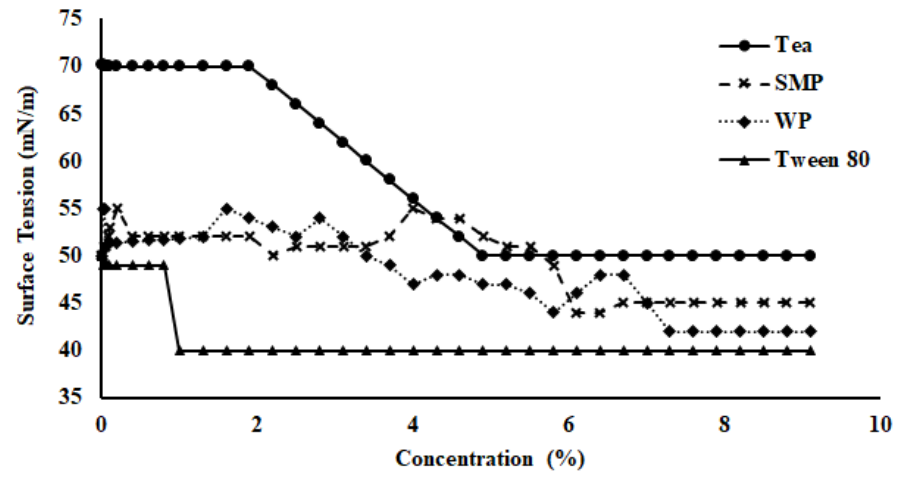

Fig. 1 Surface tension analysis of black tea along with its additives

\section{B. Foaming Characteristics}

Total height (liquid height + foam height) of tea solutions was measured by the DFA. Fig 2a shows the total height of black tea containing SMP, Fig $2 b$ for WP and Fig 2c for Tween 80, in comparison with coffee (control). Initially, when black tea was injected through the syringe into the cylinder, it showed small amount of foam on the surface. With passing of air through liquid, the foam increased for fraction of seconds and then subsided. The foam height achieved was $218 \mathrm{~mm}$ at $50.86 \mathrm{~s}$, and it dropped to $55 \mathrm{~mm}$ as time passed from $100 \mathrm{~s}$ to $600 \mathrm{~s}$. Fig $2 \mathrm{~b}$ confirmed that addition of whey protein in black tea improved the foaming capacity and total height of foam compared to black tea; whereas, addition of Tween 80 showed less effect on foam height (Fig 2c).

The time of maximum foam height indicates the time for which the foam can stay at the maximum height (KRÜSS DFA100, 2012). Whey protein at $6 \%$ concentration in black tea indicated retention of maximum foam height (200-210 $\mathrm{mm}$ ) for 60-65 s (Fig 3). To compare the stability of maximum foam height, coffee foam was selected as reference. For tea foam, it was found that addition of $6 \%$ WP resulted in time of maximum foam height $(63.65 \mathrm{~s})$ similar to that of the coffee $(63.74 \mathrm{~s})$; however, 6\% SMP required 6\% lesser time to attain maximum foam height compared to coffee foam (Fig 3). Other additives in tea were incomparable with coffee foam.

Bubble count was recorded with respect to time and average bubble count for respective solutions has been depicted (Fig. 4). It was observed that addition of whey protein improved the foamability compared to SMP and Tween 80 . Whey protein at $6 \%$ concentration showed better foam characteristics as compared to all other additives. Tea with $0.01 \%$ Tween 80 showed maximum bubble count $(210,17 \%$ lesser than that of the coffee), followed by $6 \%, 8 \%$ SMP, $4 \%$ and $8 \% \mathrm{WP}, 2 \%$ SMP and 2\% WP (Fig 4).

\section{GC-MS/MS analysis}

Caffeine was observed to be the most abundant, polar component in tea (Table 1). Past researchers have corroborated the surface activity of caffeine [11], [12], and 

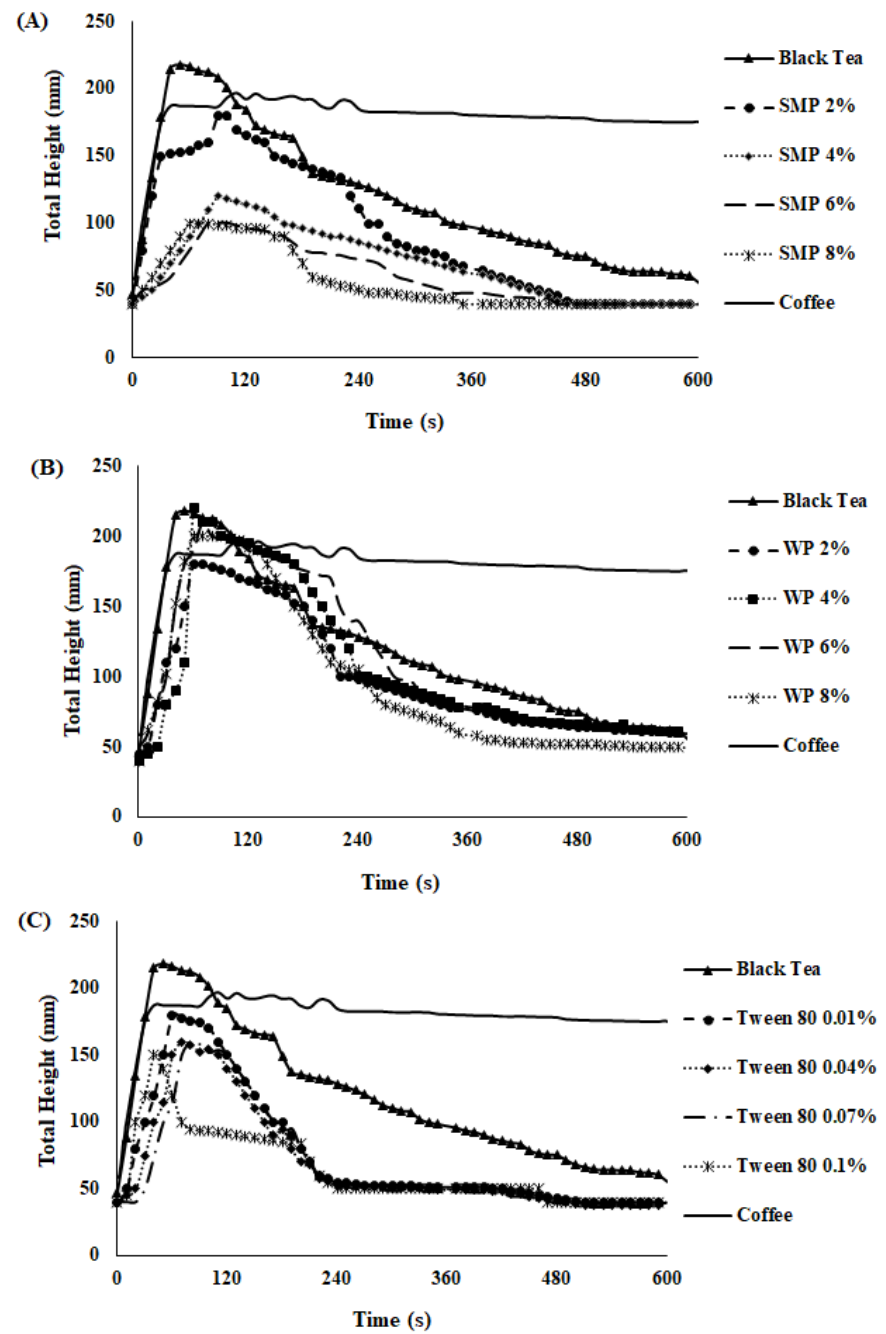

Fig. 2 Total height of the solution after foaming in tea (A: SMP, B: WP and C: Tween 80).

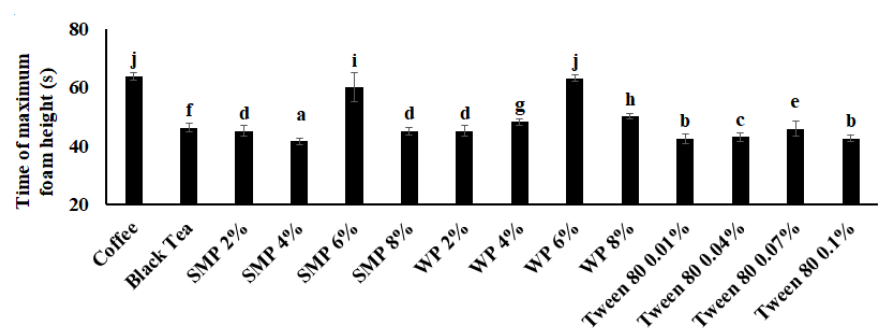

Fig. 3 Time of maximum foam height in tea. Different letter indicates significant difference at $\mathrm{p} \leq 0.05$.

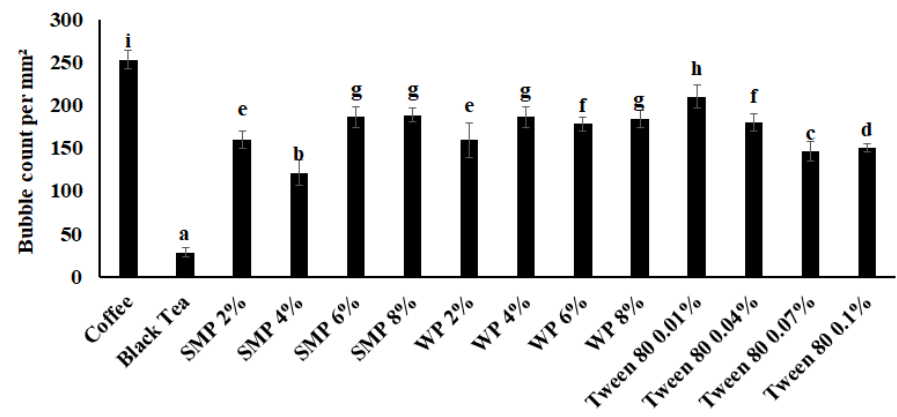

Fig. 4 Bubble count in tea solutions (per $\mathrm{mm}^{2}$ ). Different letter indicates significant difference at $\mathrm{p} \leq 0.05$. therefore we opine that caffeine could be the prime source of foam in this beverage. It has been reported that caffeine forms complexes with other compounds present in the solution, and is responsible for the foamability. Similarly caffeine alone shows foam in water; therefore in case of tea and coffee foam it could be the reason for foam formation [13].

Through non-polar component analysis, hydrocarbons with long carbon chain were also detected (Table 1). Based on the data, both polar and non-polar components have been found responsible for the formation of self-assembly, resulting in surfactant structure. Foam is also associated in reduction of surface tension and foam generation in tea. Surface tension analysis and foaming nature of tea in the present endeavor indicate the presence of surface active components, which could be in the form of catechins or proteins, similar to a previous claim by researchers [12].

TABLE I

POLAR AND NON-POLAR COMPONENTS OBTAINED By GCMS-MS ANALYSIS OF TEA

\begin{tabular}{c|c|c|c}
\hline \multicolumn{4}{c}{ Polar tea components } \\
\hline S. No & RT & Name of the compound & Peak Area \% \\
\hline 1. & 32.47 & Acetonylacetone dioxime & 0.23 \\
\hline 2. & 49.14 & Caffeine & 96.77 \\
\hline 3. & 51.74 & 12-Tridecynoic acid, methyl ester & 0.54 \\
\hline 4. & 53.80 & Oleic Acid & 2.45 \\
\hline \multicolumn{4}{|c}{ Non-polar tea components } \\
\hline S. No & RT & Name of the compound & Peak Area \% \\
\hline 1. & 3.09 & Cyclohexane, methyl- & 30.02 \\
\hline 2. & 3.75 & 2-Heptanol, 4-methyl- & 0.88 \\
\hline 3. & 3.94 & Toluene & 1.58 \\
\hline 4. & 5.04 & 9-Acetoxynonanal & 0.83 \\
\hline 5. & 20.35 & Methoxyacetic acid, 4-tridecyl & 0.60 \\
\hline 6. & 24.62 & Hydroxylamine, O-decyl- & 0.70 \\
\hline 7. & 30.02 & Benzene, (1-methyldodecyl)- & 1.52 \\
\hline 8. & 31.84 & Phytol & 0.79 \\
\hline 9. & 34.36 & Decane, 2,3,5,8-tetramethyl- & 0.66 \\
\hline 10. & 43.04 & 4-Tridecene, (Z)- & 0.22 \\
\hline 11. & 48.17 & 9-Hexadecenoic acid & 1.38 \\
\hline 12. & 53.61 & $n$-Hexadecanoic acid & 0.82 \\
\hline & &
\end{tabular}

\section{A. Sensory analysis}

The scores of sensory attributes for tea with additives have been graphically represented with the help of radar chart (Fig 5). Sensory evaluation revealed that addition of WP and Tween 80 showed insignificant effect on overall acceptability while addition of SMP to tea showed desirable scores for sensory. The panelists scored more for colour and aroma compared to taste and aftertaste especially when whey protein and Tween 80 were added in tea. Though addition of whey protein resulted in significant increase of foaming behavior of tea but the same was not favored by the sensory panel due to the characteristic odour of whey protein. In samples with Tween 80, no change was observed in colour compared to the control sample; however panelists disliked the oil like odour of 
the surfactant in the samples. Unlike the other two additives, panelists preferred SMP in at $6 \%$ concentration.

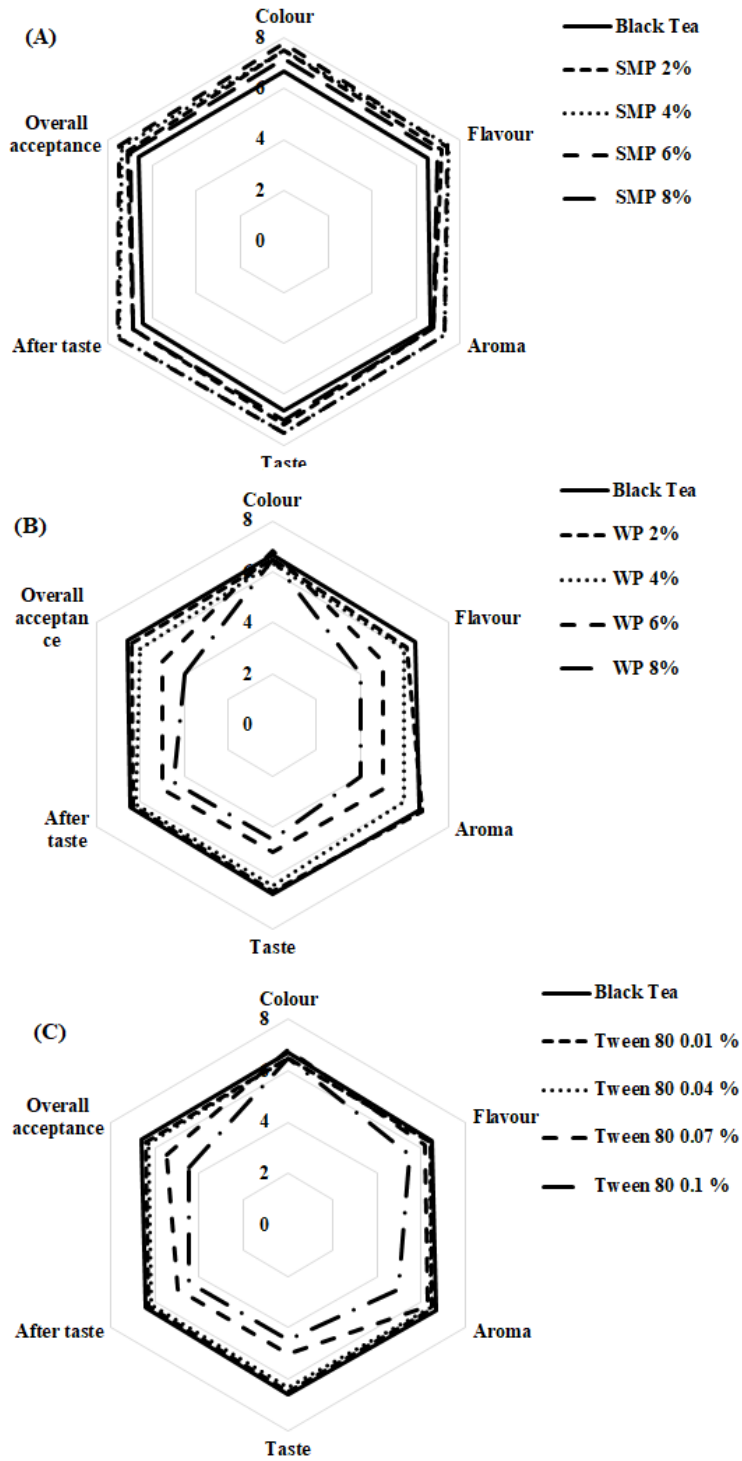

Fig. 5 SENSORY ANALYSIS OF TEA (A: SMP, B: WP, C: TwEen 80)

\section{CONCLUSION}

Results of this study showed that foam characteristics of black tea were improved by the addition of whey protein $(6 \%)$. Tensiometric analysis showed reduction in surface tension, explaining that tea possesses surface active components. This find was supported by GC-MS/MS analysis, and caffeine, a known surfactant, was found to be present as a polar compound in tea. This observation justified the premise that foam generation in tea was due to the surface activity of caffeine along with long chain hydrocarbons present. Though WP showed better foaming behavior, sensory attributes for SMP $(6 \%)$ in tea were more preferred compared to WP and Tween 80 .

\section{ACKNOWLEDGMENT}

Authors would like to acknowledge Ministry of Food Processing Industries, Government of India for funding the project. First author acknowledges Indian Council of Medical Research, Government of India for fellowship.

\section{REFERENCES}

[1] M. Khezri, S. Shahriari, and L. Shahsavani, "The effect of xanthan gum and temperature on foam stability of milk-based espresso coffees", $J$. Food Biosci. Tech., vol. 7, 2017, pp.15-22.

[2] Z. Zhu, Y. Wen, J. Yi, Y. Cao, F. Liu, and D. Julian McClements, "Comparison of natural and synthetic surfactants at forming and stabilizing nanoemulsions: Tea saponin, Quillaja saponin, and Tween 80", J. Colloid Interface Sci., 2018, https://doi.org/10.1016/j.jcis.2018.10.024.

[3] M.G. Ferruzzi, and R.J. Green, "Analysis of catechins from milk - tea beverages by enzyme assisted extraction followed by high performance liquid chromatography", Food Chemistry, vol. 99, 2006, pp. 484-491. https://doi.org/10.1016/j.foodchem.2005.08.010

[4] S.M. Henning, C. Fajardo-lira, H.W. Lee, A.A. Youssefian, V.L.W. Go, and D. Heber, "Catechin content of 18 teas and a green tea extract supplement correlates with the antioxidant capacity", Nutr. Cancer, vol. 45, 2003, pp. 226-235. https://doi.org/10.1207/S15327914NC4502_13

[5] ASTM, "Standard Test Method for Surface and Interfacial Tension of Solutions of Surface Active Agents", D1331-89, ASTM International, 2001.

[6] S. Samanta, and P. Ghosh, "Chemical Engineering Research and Design Coalescence of bubbles and stability of foams in aqueous solutions of Tween surfactants", Chem. Eng. Res. Des., vol. 89, 2011, pp. 23442355. https://doi.org/10.1016/j.cherd.2011.04.006

[7] K. Oetjen, C. Bilke-krause, M. Madani, and T. Willers, "Temperature effect on foamability, foam stability, and foam structure of milk", Colloids Surf. A Physicochem. Eng. Asp., vol. 460, 2014, pp. 280-285. https://doi.org/10.1016/j.colsurfa.2014.01.086

[8] P.K. Ghosh, S. Chatterjee, and P. Bhattacharjee, "Removal of rancidacid odor of expeller-pressed virgin coconut oil by gamma irradiation: evaluation by sensory and electronic nose technology", Food Bioproc. Tech., vol. 9, 2016, pp.1724-1734. https://doi.org/10.1007/s11947-016-1752-8

[9] S. Ranganna, "Handbook of analysis and quality control for fruit and vegetable products", 1986, Tata McGraw-Hill Education.

[10] B. Cai, and S. Ikeda, "Effects of the conjugation of whey proteins with gellan polysaccharides on surfactant-induced competitive displacement from the air-water interface", J. Dairy. Sci., vol. 99, 2016, pp. 1-10. https://doi.org/10.3168/jds.2015-10765

[11] E. Illy, and L. Navarini, "Neglected Food Bubbles: The Espresso Coffee Foam", Food Biophysics, vol. 6, 2011, pp. 335-348 https://doi.org/10.1007/s11483-011-9220-5

[12] L. Shen, X. Wang, Z. Wang, Y. Wu, and J. Chen, "Studies on tea protein extraction using alkaline and enzyme methods", Food Chemistry, vol. 107, 2008, pp. 929-938. https://doi.org/10.1016/j.foodchem.2007.08.047

[13] C. Zheng, "Complexation assisted foam fractionation of caffeine from its aqueous solution", 2014, Ph. D. Dissertation in Technical University of Munich, Germany. 

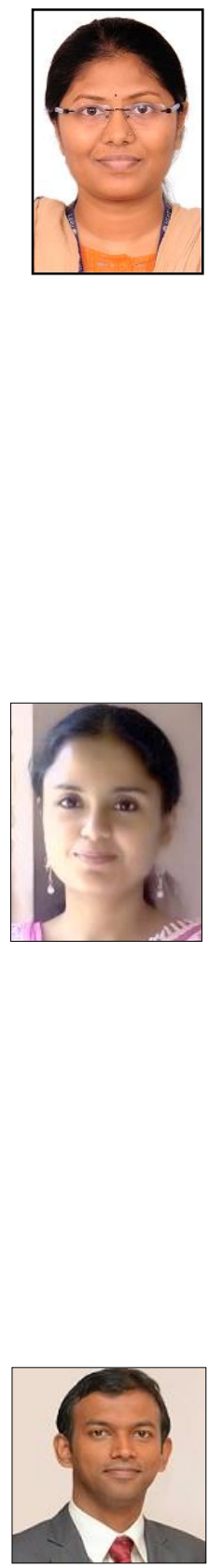

Dr. Jeyan Arthur Moses is currently working as Assistant Professor in Indian Institute of Food Processing Technology, Ministry of Food Processing Industries, Thanjavur, India. He has completed his Ph.D. in 2014 from Indian Institute of Food Processing Technology and B.Tech. and M.Tech. from Karunya University, Coimbatore. He was awarded Gold Medal and received the Best Outgoing Student Award and Food Processing Award. Dr. Jeyan is ICAR-NET qualified and received Doctoral Research Assistantship from IIFPT, Thanjavur and Graduate Research Assistantship from the University of Manitoba during his Ph.D. He has authored over 60 publications in reputed journals, popular magazines and book chapters. He is also a member of selected professional bodies and serves as editorial board member and reviewer for reputed journals. His research area is on 3D printing of foods, computational modeling of food processing systems and nanoscale food processing.

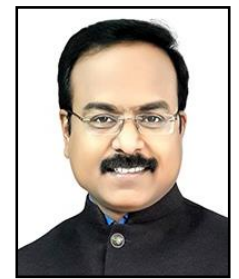

Dr. C. Anandharamakrishnan is the Director of Indian Institute of Food Processing Technology (IIFPT), Thanjavur. He has 19 years of experience in $R \& D$ and administration at the CSIR - Central Food Technological Research Institute (CFTRI), a prestigious food research institution in India. He was Principal Scientist and Coordinator for the Academy of Scientific \& Innovative Research (AcSIR) at CSIR-CFTRI. Dr. Anandharamakrishnan is the elected Fellow of the Royal Society of Chemistry (FRSC), Fellow of Royal Society of Biology (FRSB) and the Institute of Engineers (FIE). He serves/served as the Editor of Journal of Food Science and Technology (Springer), Editorial Board member of various international journals and as a peer reviewer for more than 20 International journals. He is the member of several professional committees and the member of the Board of Studies in various academic institutions. He is the recipient of several awards including, Prof. Jiwan Singh Sidhu Award 2010 from the Association of Food Scientists and Technologists (India), Best Scientist Award 2012, Best Applied Research Paper 2014 by CSIR-CFTRI and Dr B.D. Tilak Chemcon Distinguished Speaker Award 2016 from the Indian Institute of Chemical Engineers (IIChE). He is also recipient of the prestigious M.S. Swaminathan Scientific Tamil Excellence Award 2017 and Dr. M. Sabir Oration Award 2017 by Indian Society of Veterinary Pharmacology and Toxicology. Recently, he has been awarded as Best Director of the year 2018 and Visionary Leader of the Year 2018 by Integrated Chamber of Commerce and Industries (ICCI). He was also conferred with Treasure Trove of Scientific Knowledge Award 2018 by MTS Academy, Chennai. $\mathrm{He}$ is the recipient of the prestigious NASI-Reliance Industries Platinum Jubilee Award 2018. 